Кривов Г. А., Матвиенко В. А., Рудъко А. Н., Баклан В. В.

АО «Украинский научно-исследовательский институт авиационной технологии». Украина, г. Киев

\title{
СОСТОЯНИЕ И ПЕРСПЕКТИВЫ РАЗВИТИЯ МИРОВОГО РЫНКА УСЛУГ ПО КОНВЕРТАЦИИ ПАССАЖИРСКИХ САМОЛЕТОВ В ГРУЗОВЫЕ
}

В статье представлены результаты аналитического обзора состояния и перспектив развития мирового, а также региональных рынков конвертированных грузовых самолетов. Рассмотрены основные организационно-технические принципы и опыт функционирования отдельных производственных структур этого сектора гражданской транспортной авиации.

Проанализированы необходимые предпосылки для создания и успешной деятельности на рынке новых проектно-производственных структур, спещиализирующихся на выполнении работ по конвертачии пассажирских самолетов в грузовые. [dx.doi.org/10.29010/086.1]

Ключевые слова: грузовой самолет; конвертированный грузовой самолет; мировой парк грузовых самолетов; структура мирового парка грузовых самолетов; состояние мирового парка грузовых самолетов; перспективы развития мирового парка конвертированных грузовых самолетов; центр конвертации, технического обслуживания и ремонта; стоимость конвертащии пассажирских самолетов в грузовые.

\section{1. Формирование, текущее состояние и перспективы развития мирового и региональных рынков конвертированных самолетов}

1.1. Конвертированные грузовые самолеты в структуре мирового парка грузовых самолетов в начале XXI столетия

По мнению авиационных специалистов, в настоящее время прослеживается тенденция к сохранению преобладания в структуре мирового парка грузовых самолетов конвертированных грузовых самолетов - переоборудованные пассажирские самолеты, эксплуатировавшиеся в течение 15-20 лет, в грузовые версии в соответствии с устоявшейся практикой продления срока их эксплуатации, над новыми специализированными грузовыми самолетами. Развитию конвертации, как отдельного сектора авиационной промышленности, способствуют отмечающийся ежегодный рост объемов мировых грузовых авиаперевозок и динамично развивающиеся региональные рынки грузовых самолетов, в первую очередь - рынок АзиатскоТихоокеанского региона (АТР).

В аналитическом обзоре, подготовленном специалистами УкрНИАТ [1], отмечается, что по состоянию на 2001 год, в структуре мирового парка грузовых самолетов - всего $\approx 1775$ единиц, конвертированных грузовых самолетов насчитывалось $\approx 1330$ ед., новых специализированных $\approx 445$ ед., что составляло $75 \%$ и $25 \%$ соответственно. Аналогичные данные представлены в обзорах
[2, 3] американской авиастроительной компании Boeing (рис. 1).

По оценке специалистов компании «Air Cargo Management Group» [4], по состоянию на 2001 год, также в структуре мирового парка грузовых самолетов преобладали конвертированные грузовые самолеты с небольшой разницей в их количестве $\approx 1220$ ед. (в [1-3] - 1330 ед.), что составляло $75 \%$ от общего числа грузовых самолетов $-\approx 1620$ ед. и только $\approx 400$ ед. $(25 \%)$ составляли новые грузовые самолеты (рис. 2).

По состоянию на 2008 год, по данным специалистов УкрНИАТ [5], несмотря на некоторое сниже-
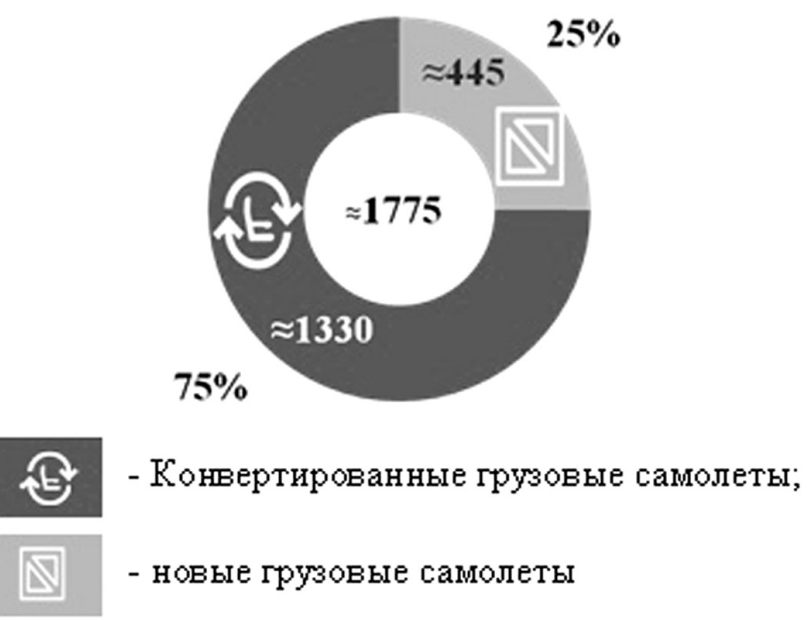

Рис. 1. Конвертированные грузовые самолеты в структуре мирового парка грузовых самолетов по состоянию на 2001 год [1-3] 


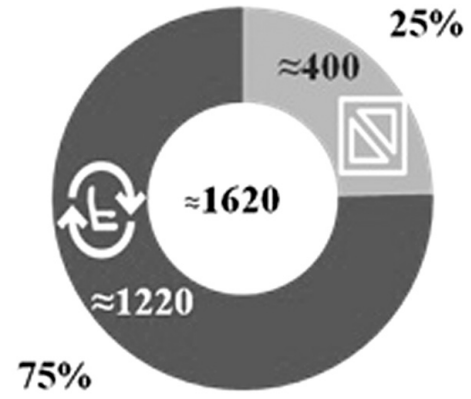

- Конвертированные грузовые самолеты;

- новые грузовые самолеты

Рис. 2. Конвертированные грузовые самолеты в структуре мирового парка грузовых самолетов по состоянию на 2001 год [4]

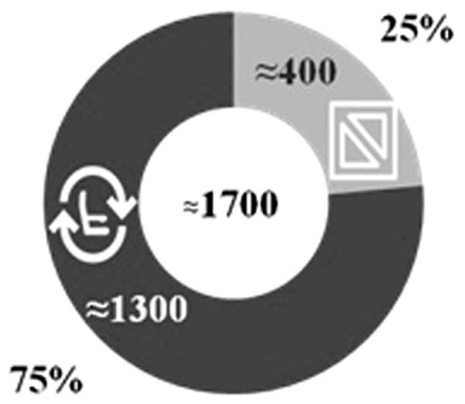

- Конвертированные грузовые самолеты;

- новые грузовые самолеты

Рис. 3. Конвертированные грузовые самолеты в структуре мирового парка грузовых самолетов по состоянию на 2008 год [5]
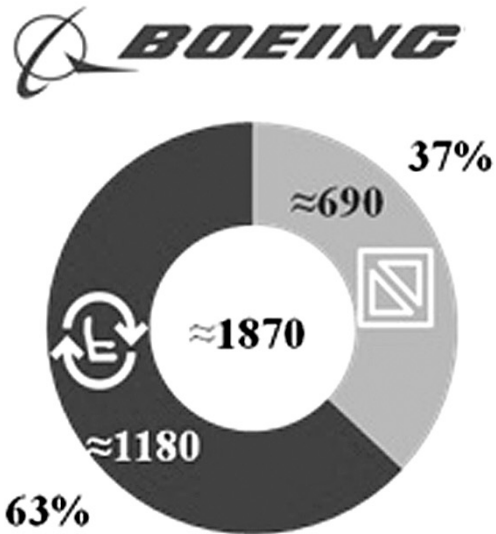

- Конвертированные грузовые самолеты; ние, по сравнению с 2001 годом, общего количества мирового парка грузовых самолетов до $\approx 1700$ ед., в его структуре также отмечается преобладание конвертированных грузовых самолетов - 1300 ед. $(75 \%)$ и только $\approx 400$ ед. (25\%) составляли новые грузовые самолеты (рис. 3 ).

По состоянию на начало 2018 года, специалисты ведущих мировых самолетостроительных компаний - американской Boeing [6] и европейской Airbus [7-9] сошлись в своих оценках касательно сохранения в структуре мирового парка грузовых самолетов преобладания конвертированных грузовых самолетов. Так, по их подсчетам, количество конвертированных грузовых самолетов составляло $\approx 1180$ и $\approx 1040$ единиц соответственно, а новых грузовых самолетов - $\approx 690$ ед. и $\approx 610$ ед. соответственно (рис. 4).

1.2. Перспективы развития мирового и региональных рынков конвертированных самолетов на период до 2037 года.

В течение 2018 - 2037 гг., по мнению зарубежных авиационных специалистов и экспертов [6-9], рынок услуг по конвертации пассажирских самолетов в грузовые имеет благоприятную перспективу. Прогнозируется, что в указанный период среднегодовой рост грузовых авиаперевозок составит около 4,2\% [6]. При этом, общая численность мирового парка грузовых самолетов может возрасти в среднем в 1,7 раза, что будет достаточным для обеспечения повышения объемов грузовых авиаперевозок.

Сравнительный анализ прогнозов ведущих мировых авиапродуцентов - Boeing [6] и Airbus [7-9] показывает достаточно высокую степень совпадения их оценок по развитию и структуре парка грузовых самолетов в период 2018-2037 гг. По их данным, мировой парк грузовых самолетов за ука-

\section{(2) AIRBUS}

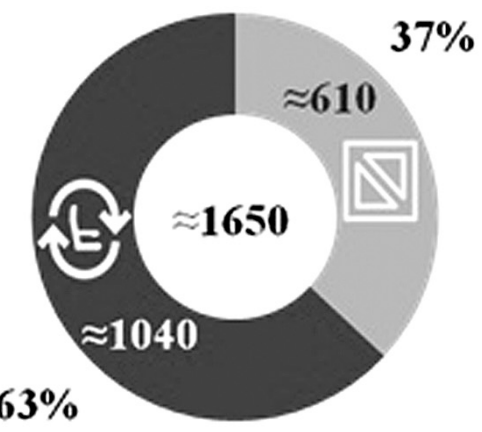

- новніе грузовые самолеты

Рис. 4. Конвертированные грузовые самолеты в структуре мирового парка грузовых самолетов по состоянию на начало 2018 года по оценкам компаний Boeing [6] и Airbus [7-9] 
Прогноз компаний Boeing и Airbus структуры парка грузовых самолетов, которые будут введены в эксплуатацию в период 2018-2037 гг.

\begin{tabular}{|c|c|c|c|}
\hline \multirow{2}{*}{$\begin{array}{c}\text { Самолетостроительная } \\
\text { компания }\end{array}$} & \multicolumn{2}{|c|}{$\begin{array}{c}\text { Ввод в эксплуатацию грузовых самолетов } \\
\text { в период 2018-2037 гг., ед. } \\
\end{array}$} & \multirow{2}{*}{$\begin{array}{c}\text { Общая численность грузовых } \\
\text { самолетов, которые будут } \\
\text { введены в эксплуатацию } \\
\text { в период 2018-2037 гг., ед. }\end{array}$} \\
\hline & $\begin{array}{c}\text { конвертированных } \\
\text { грузовых самолетов }\end{array}$ & $\begin{array}{c}\text { новых грузовых } \\
\text { самолетов }\end{array}$ & \\
\hline Boeing & $\approx 1670$ & $\approx 980$ & $\approx 2650$ \\
\hline Airbus & $\approx 1560$ & $\approx 830$ & $\approx 2390$ \\
\hline
\end{tabular}

занный период пополнится на $\approx 2,4-2,7$ тыс. единиц, среди которых будут преобладать конвертированные самолеты (63-65\%). Так, согласно прогнозу компании Boeing [6], мировой парк грузовых самолетов пополнится на $\approx 2650$ ед., из которых $\approx 1670$ будут составлять конвертированные грузовые самолеты, $\approx 980$ ед. - новые грузовые самолеты. Прогноз компании Airbus [7-9] показывает, что мировой парк грузовых самолетов пополнится на $\approx 2390$ ед., из которых $\approx 1560$ будут составлять конвертированные грузовые самолеты, $\approx 830$ ед. новые грузовые самолеты (табл. 1).

По прогнозу специалистов компании Boeing [6], из состава действующего на сегодня парка грузовых самолетов ( $\approx 1870$ ед.) в течение ближайших 20 лет будет выведено $\approx 1260$ единиц. С учетом указанного, а также прогнозируемого пополнения мирового парка грузовых самолетов (на $\approx 2650$ ед.), его общая численность возрастет до $\approx 3260$ ед. Аналогичные расчеты проведены специалистами компании Airbus $[8,9]$. По их прогнозу, в период 2018-2037 гг., с учетом снятия с эксплуатации $\approx 1310$ ед. грузовых самолетов и прогнозируемого пополнения мирового парка грузовых самолетов на $\approx 2390$ ед., его общая численность возрастет до $\approx 2730$ единиц (рис. 5).

Результаты сравнительного анализа прогнозных данных компаний Boeing [6] и Airbus [7-9] относительно емкости региональных рынков грузовых самолетов в период 2018-2037 гг., свидетельствует о некоторых отличиях в оценках специалистов.

В первую очередь, это касается определения самого емкого рыка. По оценке специалистов компании Boeing [6], ожидается, что таким станет рынок АТР $-\approx 1150$ грузовых самолетов, обогнав Североамериканский рынок с объемом $\approx 1100$ самолетов. В свою очередь специалисты компании Airbus [7-9] предполагают, что позицию самого крупного регионального рынка грузовых самолетов сохранит Североамериканский рынок с потребностью в $\approx 1080$ ед., а рынок АТР выйдет на второе место - с объемом $\approx 800$ самолетов. Согласно прогнозируемым оценкам специалистов компаний

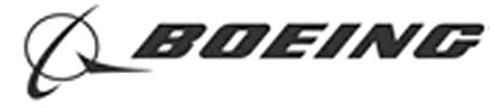

$\approx 3260$

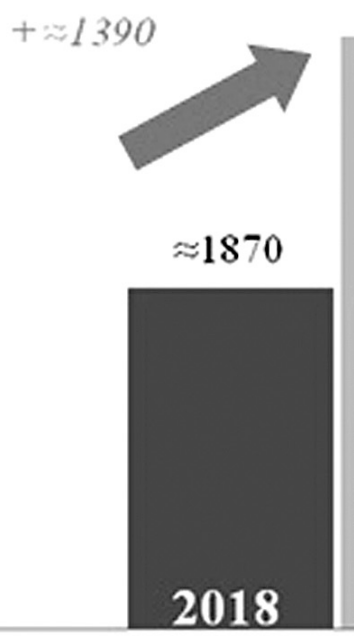

\section{$\approx 260$}

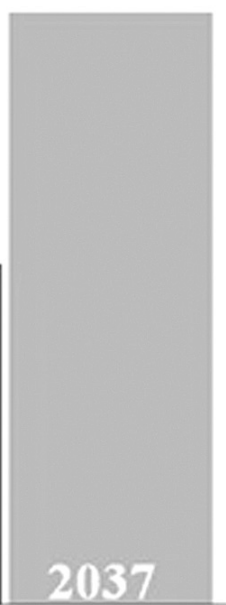

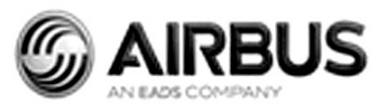

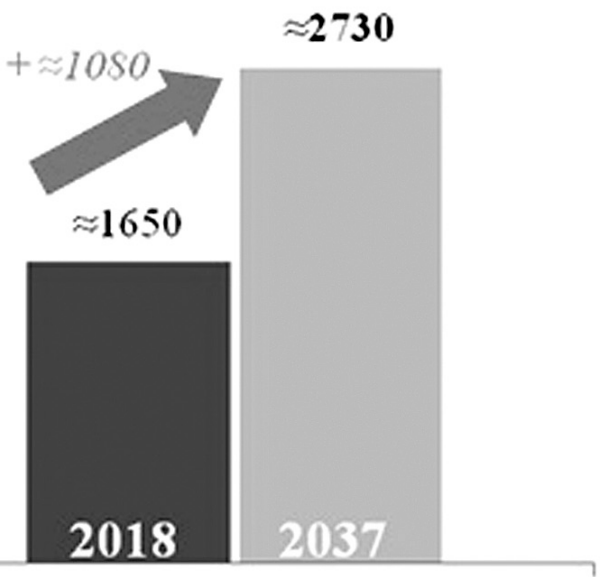

Рис. 5. Прогнозы компаний Boeing и Airbus по развитию мирового парка эксплуатируемых грузовых самолетов в период до 2037 г. [6-9] 
Прогноз компаний Boeing и Airbus объемов региональных рынков грузовых самолетов в период 2018-2037 гг.

\begin{tabular}{|c|c|c|}
\hline \multirow{2}{*}{$\begin{array}{c}\text { Региональный рынок грузовых } \\
\text { самолетов }\end{array}$} & \multicolumn{2}{|c|}{ Прогнозируемые объемы региональных рынков, ед. } \\
\hline & Boeing & Airbus \\
\hline Североамериканский & $\approx 1100$ & $\approx 1080$ \\
\hline Азиатско-Тихоокеанский & $\approx 1150$ & $\approx 800$ \\
\hline Европейский & $\approx 420$ & $\approx 410$ \\
\hline Латиноамериканский & $\approx 120$ & $\approx 100$ \\
\hline Ближневосточный & $\approx 200$ & $\approx 140$ \\
\hline $\mathrm{CH \Gamma}$ & $\approx 150$ & $\approx 90$ \\
\hline Африканский & $\approx 120$ & $\approx 110$ \\
\hline ВСЕГО: & $\approx 3260$ & $\approx 2730$ \\
\hline
\end{tabular}

Boeing и Airbus, замкнет тройку лидеров Европейский рынок грузовых самолетов с объемом $\approx 410-420$ единиц.

Самыми слабо развивающимися региональными рынками грузовых самолетов, по мнению Boeing, будут Латиноамериканский и Африканский, которые приобретут $\approx 120$ ед., а согласно прогнозной оценке Airbus - рынок СНГ с объемом всего $\approx 90$ самолетов (табл. 2).

В период 2018-2037 гг. прогнозируется, что наиболее востребованными конвертированными грузовыми самолетами станут легкие узкофюзеляжные самолеты Boeing 737 и Airbus A320/A321. В указанный период объем мирового спроса на эти самолеты оценивается около $\approx 1600$ единиц $[11,12]$. По предварительным оценкам, спрос на конвертированные самолеты Boeing 737 составит $\approx 1000$ ед., Airbus A320/A321 - ₹600 ед. Специалисты компании Boeing [11], учитывая постоянно растущий рынок грузовых самолетов в АТР, предполагают, что он будет нуждаться более чем в $\approx 300$ ед. конвер- тированных грузовых самолетах Boeing 737 и Airbus A320/A321. При этом, в качестве основных заказчиков этих самолетов рассматривается Китай. По мнению западных экспертов, самолеты Boeing 737 и Airbus A320/A321 найдут широкое применение на региональных (внутренних) маршрутах для транспортировки экспресс-грузов (рис. 6).

Увеличение парка конвертированных грузовых самолетов тяжелого класса будет обеспечиваться, преимущественно, за счет поставок широкофюзеляжных самолетов [11], например, таких как Boeing 747, Boeing 777, Boeing 767, Boeing/MDC MD-11.

\section{2. Мировой и региональный рынок услуг по} конвертации пассажирских самолетов в грузовые

2.1. Ведущие мировые и региональнье компании, специализирующиеся на конвертащии самолетов

Стабильный рыночный спрос на конвертированные грузовые самолеты обусловлен завершением в ближайшей перспективе срока эксплуатации

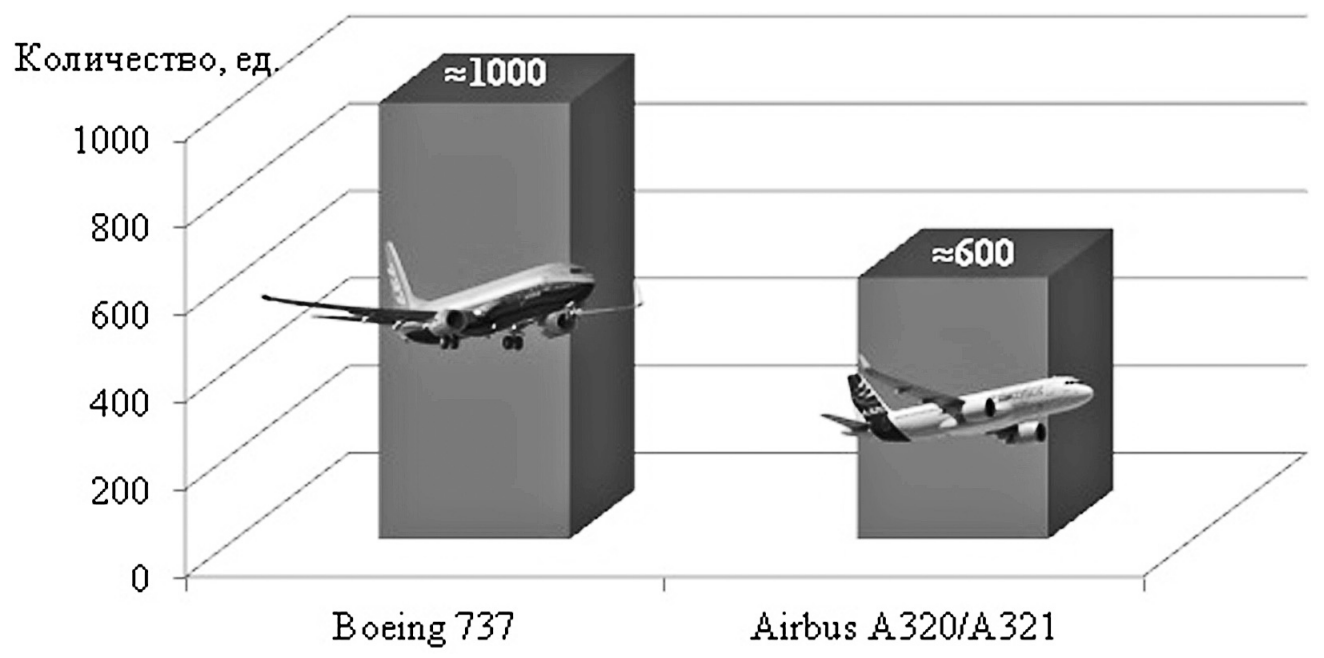

Рис. 6. Прогноз наиболее востребованных конвертированных узкофюзеляжных грузовых самолетов в период 2018-2037 гг. [11, 12] 
большого количества ранее выпущенных специализированных грузовых самолетов при одновременном наличии на рынке достаточно большого количества пассажирских гражданских самолетов, ресурс которых близок к исчерпанию. Это создает предпосылки для переоборудования пассажирских гражданских самолетов в грузовые.

В то же время, по мнению экспертов, отдельные авиакомпании не спешат отдавать свои, отслужившие 15-20 лет пассажирские самолеты на переоборудование в грузовые [5]. Такие действия они объясняют необходимостью обеспечения пассажирских авиаперевозок в условиях постоянного увеличения их объемов. Дефицит грузовых самолетов на рынке приводит к увеличению их стоимости, что может поставить под сомнение экономическую целесообразность переоборудования пассажирских самолетов. Поэтому соображения рентабельности являются одними из главных факторов, определяющих выбор авиакомпаний покупать новый или конвертированный грузовой самолет.

Таким образом, ключевым условием развития конвертации - отдельного сектора авиационной промышленности, является рост объема грузовых авиаперевозок, неразрывно связанного с состоянием мировой экономики.

Как правило, работы по конвертации пассажирских самолетов в грузовые выполняют [5, 12]:

- компании-производители самолетов (original equipment manufacturer);

- компании, осуществляющие конвертацию самолетов по лицензии компаний-производителей;

- компании, не имеющие соглашений с компаниями-производителями самолетов на их конвертацию, которые самостоятельно выполняют конвертацию самолетов.

В соответствии с международной практикой, на каждый конвертированный самолет, в том числе и компанией, не имеющей соглашения с компанией-производителем самолетов, оформляется сертификат соответствия проведенных работ установленным требованиям. В этой связи, в последнее время отмечается тенденция передачи компаниями-производителями самолетов полномочий по сертификации конвертированных самолетов другим компаниям, спе- циализирующимся на таком виде деятельности. Например, центр конвертации компании Airbus Elbe Flugzeugwerke GmbH (EFW, г. Дрезден, ФРН) задействуется для сертификации новых моделей конвертированных грузовых самолетов компании Boeing.

По данным компаний IBA [10], а также American friendship world air cargo corporation [12], составлен перечень компаний, которые на сегодняшний день имеют сертификаты на конвертированные самолеты, а также компаний, находящихся в стадии их получения (табл. 3).

Также отметим увеличение с каждым годом количества компаний, которые успешно осваивают

Таблица 3

Перечень компаний, специализирующихся на выполнении работ по конвертации пассажирских самолетов в грузовые

\begin{tabular}{|c|c|}
\hline Название компании & Модель самолета \\
\hline \multicolumn{2}{|c|}{$\begin{array}{l}\text { Компании, имеющие сертификаты } \\
\text { на конвертированные самолеты }\end{array}$} \\
\hline $\begin{array}{l}\text { Aeronautical Engineers, Inc., } \\
\text { Pemco World Air Services, } \\
\text { Taikoo Aircraft Engineering Co. }\end{array}$ & Boeing 737-300/-400 \\
\hline $\begin{array}{l}\text { Israel Aerospace Industries, } \\
\text { Taikoo Aircraft Engineering Co., } \\
\text { KAL Aerospase, } \\
\text { SIA Engineering }\end{array}$ & Boeing 747-400 \\
\hline $\begin{array}{l}\text { Pemco World Air Services, } \\
\text { Precision Conversions }\end{array}$ & Boeing 757-200 \\
\hline $\begin{array}{l}\text { Boeing, } \\
\text { Israel Aerospace Industries, } \\
\text { ST Aero }\end{array}$ & Boeing 767-200/-300 \\
\hline Aeronautical Engineers, Inc. & MD-80 \\
\hline Aeronautical Engineers, Inc. & $\mathrm{CRJ}$ \\
\hline $\begin{array}{l}\text { Aeronavali, } \\
\text { ST Aero }\end{array}$ & MD-11 \\
\hline $\begin{array}{l}\text { Aeronavali, } \\
\text { ST Aero }\end{array}$ & DC-10 \\
\hline Pacavi International inc. & A320/A321 \\
\hline \multicolumn{2}{|c|}{$\begin{array}{c}\text { Компании, находящиеся в стадии получения сертификатов } \\
\text { на конвертированные самолеты }\end{array}$} \\
\hline $\begin{array}{l}\text { Israel Aerospace Industries, } \\
\text { Pemco World Air Services }\end{array}$ & Boeing 737-700 \\
\hline $\begin{array}{l}\text { Boeing, } \\
\text { Israel Aerospace Industries, } \\
\text { Aeronautical Engineers, Inc., } \\
\text { Pemco World Air Services }\end{array}$ & Boeing 737-800 \\
\hline $\begin{array}{l}\text { Boeing, } \\
\text { Israel Aerospace Industries }\end{array}$ & Boeing 777-200ER/-300ER \\
\hline $\begin{array}{l}\text { Airbus Elbe Flugzeugwerke GmbH, } \\
\text { ST Aero }\end{array}$ & A330-200/-300 \\
\hline $\begin{array}{l}\text { Airbus Elbe Flugzeugwerke GmbH, } \\
\text { ST Aero }\end{array}$ & A320/A321 \\
\hline
\end{tabular}


и выполняют работы по конвертации, в том числе: в США - Flightstar, HAECO Americas, Dotan, Goodyear/AeroTurbine; Канаде - KF Aerospace; Бразилии - Varig Engineering \& Maintenance; Китае - Hong Kong Aircraft Engineering Company, Aircraft Maintenance \& Engineering Corporation; Коста-Рике - COOPESA.

2.2. Текущие и прогнозные показатели стоимости работ по конвертации самолетов

По данным компании IBA [10], в 2017 - начале 2018 гг., минимальная стоимость работ по конвертации одного пассажирского самолета в грузовой составляла 2,3-2,5 млн. дол. США для самолетов McDonnell Douglas MD-80, Boeing B737-300, а максимальная - 23,5 млн. дол. США для самолета Boeing 747-400. В свою очередь удельная стоимость таких работ варьировалась от 65-77 дол. США/кг массы пустого самолета для самолетов MD-80, B737-300, до 150-155 дол. США/кг массы пустого самолета - для В767-300, В747-400 (рис. 7).

Также специалисты компании IBA [10] оценили ориентировочно стоимость перспективных (запланированных в течение 2018-2037 гг.) работ по конвертации пассажирских самолетов более поздних разработки и производства в грузовые. Согласно сделанным ими прогнозным оценкам, абсолютная стоимость таких работ будет находиться в пределах от $\approx 4,0$ млн. дол. США - для самолетов B737-700, В737-800NG до 16,0 млн. дол. США для A330-300, удельная стоимость будет колебаться от $\approx 90,0$ дол. США/кг массы пустого самолета для самолета В737-700 до $\approx 130,0$ дол. США/кг массы пустого самолета для самолета А330-300 (рис. 8).

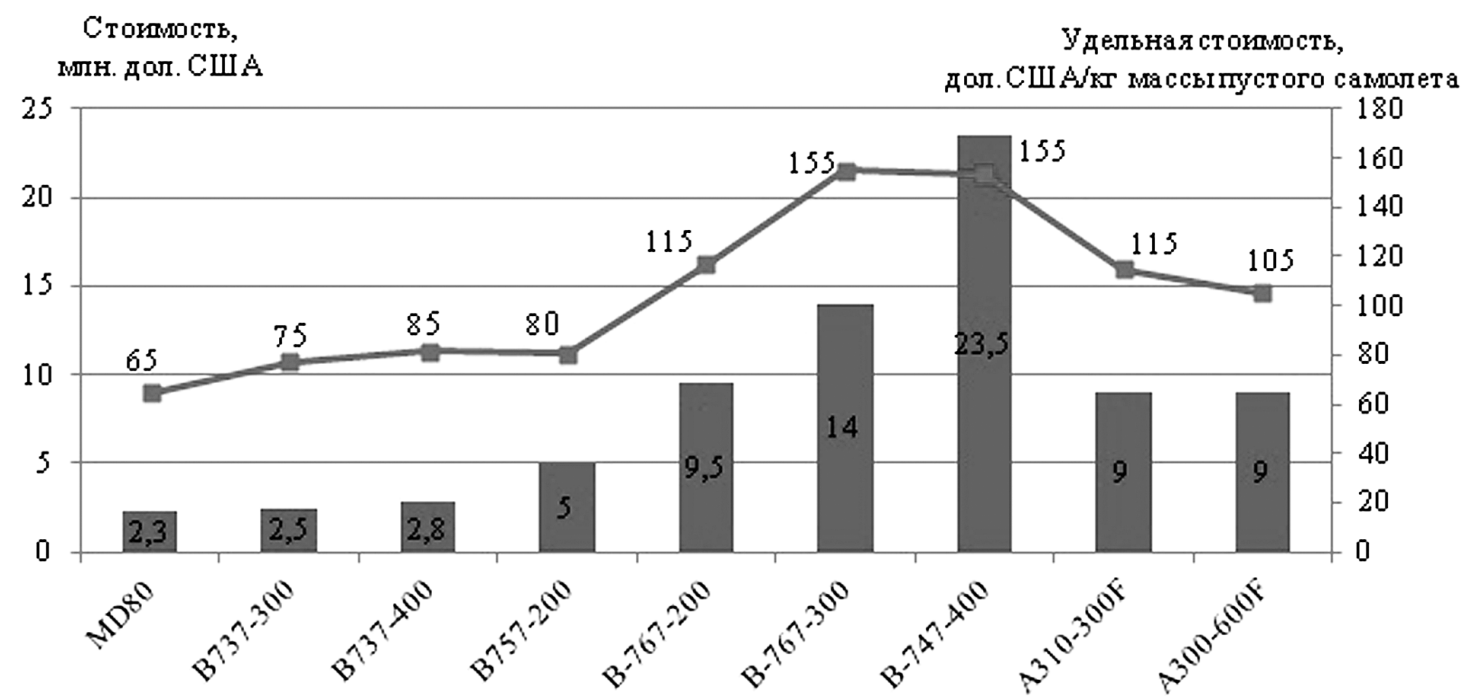

Рис. 7. Стоимость/удельная стоимость работ по конвертации пассажирских самолетов в грузовые в 2017 - начале 2018 гг. [10]

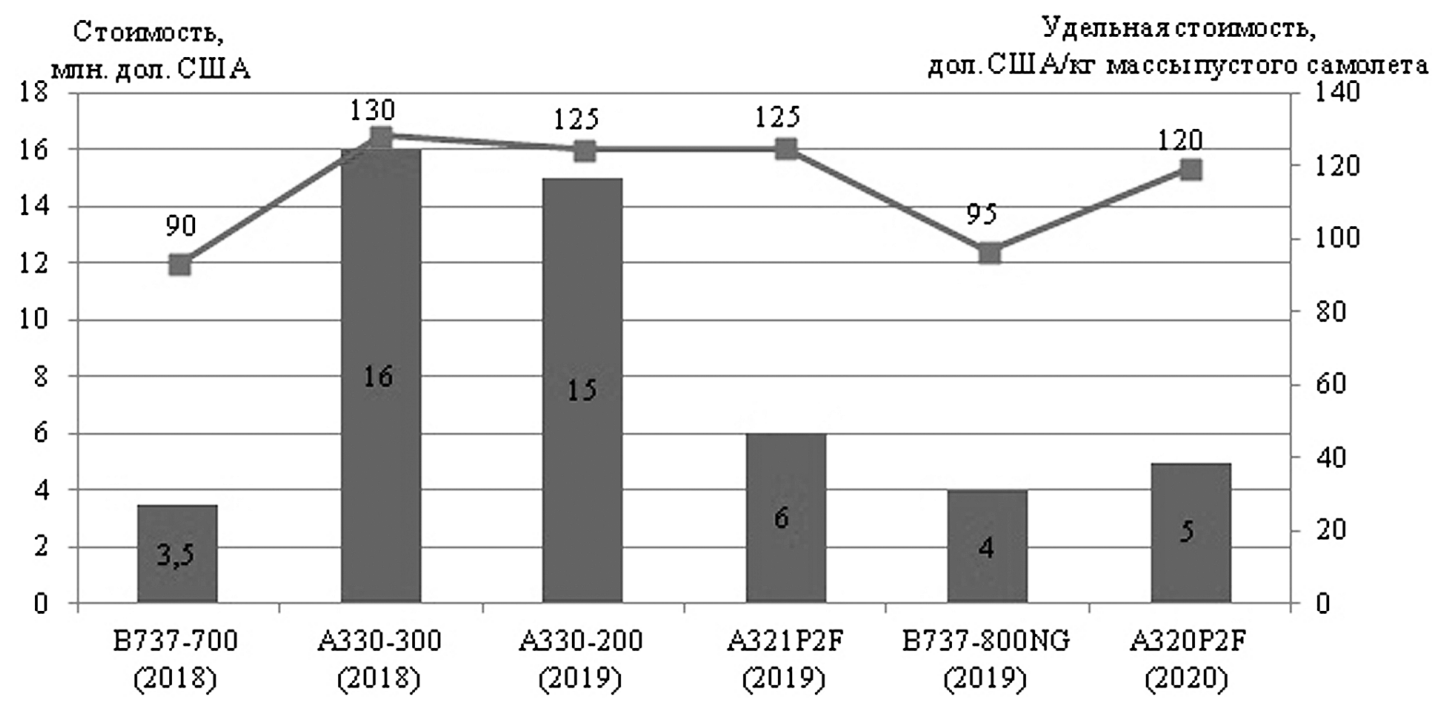

Рис. 8. Прогноз стоимости/удельной стоимости работ по конвертации пассажирских самолетов в грузовые в период 2018-2037 гг. [10] 
На сегодняшний день, по оценке американских авиационных экспертов [12], конкурентоспособным считается конвертированный грузовой самолет, если его стоимость составляет 25-30\% от стоимости нового грузового самолета. Конкурентоспособная стоимость легкого конвертированного грузового самолета составляет 10-12 млн. дол. США, среднего узкофюзеляжного - 15-20 млн. дол. США, среднего широкофюзеляжного - 20-30 млн. дол. США, тяжелого широкофюзеляжного - 55-65 млн. дол. США.

Согласно исследованиям, проведенным специалистами компании IBA [10], в укрупненную структуру стоимости конвертированного грузового самолета входят (рис. 9):

- остаточная рыночная стоимость пассажирского самолета по достижении им 20-летнего срока эксплуатации;

- стоимость работ по конвертации;

- прочие расходы (расходы на техническое обслуживание, транспорт, управление, отсутствие доходов от эксплуатации и т.д.).

Подтверждением этому служат приведенные специалистами компании IBA [10] примеры укрупненных данных стоимости различных моделей конвертированных грузовых самолетов производства компаний Boeing и Airbus (табл. 4).

Необходимо отметить, по оценкам экспертов [14], стоимость конвертированного самолета зависит также от его технического состояния и объема технического обслуживания и ремонта (как правило, совмещается с выполнением работ по конвертации). В этой связи, интерес вызывает представленная Международной организацией гражданской авиации (ИКАО) статистика [17], согласно которой ежегодные расходы на техническое обслуживание и ремонт (ТО и Р) возрастают. По данным 47 ведущих мировых авиакомпаний, в 2015 году расходы на эти цели для одного узкофюзеляжного самолета оценивались в более чем 2,5 млн. дол. США (в 2014 году этот показа-

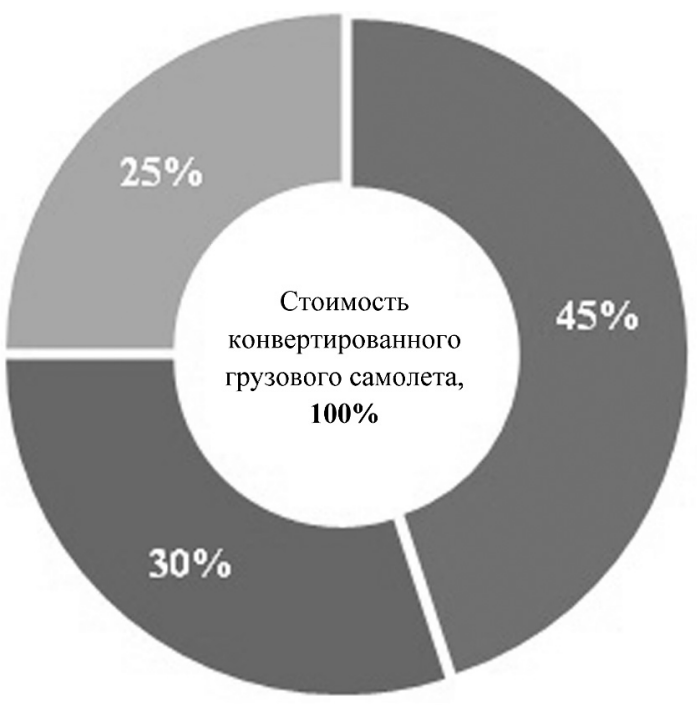

口 Остаточная рыночная стонмость пассажнрского самолета

- Стонмостьработ по конвертацни

Прочне расходы

Рис. 9. Укрупненная структура стоимости конвертированного грузового самолета [10]

тель составлял 2,3 млн. дол. США). Также отмечается рост удельной стоимости - с 743 дол. США/за час полета в 2014 году до 854 дол. США/за час полета в 2015 году.

\section{3. Организационно-технические аспекты работ по конвертации пассажирских самолетов в грузовые}

3.1. Типичные организационные модели деятельности центров конвертации

Опыт компаний по конвертации пассажирских самолетов в грузовые показывает, что они используют различные модели в своей деятельности. Это

Таблица 4

Укрупненные данные стоимости конвертированных грузовых самолетов

\begin{tabular}{|c|c|c|c|c|}
\hline Модель самолета & $\begin{array}{c}\text { Остаточная рыночная } \\
\text { стоимость } \\
\text { пассажирского } \\
\text { самолета (после } \\
\text { 20 лет эксплуатации), } \\
\text { млн. дол. США }\end{array}$ & $\begin{array}{c}\text { Стоимость работ } \\
\text { по конвертации, } \\
\text { млн. дол. США }\end{array}$ & $\begin{array}{c}\text { Прочие расходы, } \\
\text { млн. дол. США }\end{array}$ & $\begin{array}{c}\text { Сонвертированного } \\
\text { самолета, } \\
\text { млн. дол. США }\end{array}$ \\
\hline Boeing 737-300 CF & 2,6 & 2,5 & 2,2 & 7,30 \\
\hline Boeing 737-400 CF & 4,0 & 2,8 & 2,4 & 9,20 \\
\hline Boeing 737-700 CF & 8,0 & 3,5 & 2,0 & 13,50 \\
\hline Boeing 737-800 CF & 11,0 & 4,0 & 2,15 & 17,15 \\
\hline Boeing 757-200 CF & 8,5 & 5,0 & 2,5 & 16,00 \\
\hline A320 CF & 11,0 & 5,0 & 2,5 & 18,50 \\
\hline A321 CF & 12,0 & 6,0 & 2,5 & 20,50 \\
\hline
\end{tabular}


может быть выполнение полного цикла работ, как правило, характерно для крупных технологически развитых авиационных компаний, или в кооперации с другими компаниями на основе аутсорсинга.

По оценкам экспертов [14], компания, получив право на конвертацию, будет задействована в этом процессе на протяжении достаточно длительного периода. Кроме этого, дополнительной привлекательности конвертации прибавляет то, что она может являться также предметом офсетной сделки. При этом, основным фактором конкурентной борьбы авиационных компаний за контракты на выполнение работ по конвертации пассажирских самолетов в грузовые называется рентабельность, которая выше, примерно в два раза, чем при производстве новых пассажирских самолетов.

Для создания и успешного функционирования центра конвертации, технического обслуживания и ремонта пассажирских самолетов иностранного производства нужно выполнить ряд основных мероприятий - нормативно-правового, организационного, технического, технологического и др. характера [16, 17]:

- нормативно-правовое обеспечение - получение сертификатов Part-145 Европейского агентства по авиационной безопасности (EASA) и FAR-145 Федерального управления гражданской авиации США (FAA);

- организационные мероприятия:

- выбор взлетно-посадочной полосы соответствующей основным тактико-техническим характеристикам (ТTX) самолетов, которые планируются для конвертации, ТО и Р;

- подготовка ангарных площадей и подсобных помещений;

- расчет необходимого количества основного производственного персонала для выполнения конвертации, ТО и Р самолетов;

- обучение и допуск инженерно-технического персонала к обслуживанию авиационной техники иностранного производства;

- технические мероприятия:

- разработка конструкторской и технологической документации на выполнение работ по конвертации самолета в соответствии с техническим заданием заказчика;

- расчет трудоемкости выполнения конвертации, ТО и Р самолетов;

- налаживание производства новых элементов конструкции (полы, боковые двери, элементы усиления и механизации);

• расчет на прочность измененной конструкции конвертированного самолета;

- мероприятия по технологической подготовке производства:

- проектирование и изготовление средств технологического оснащения;
- выбор и приобретение необходимого оборудования, инструмента;

- разработка технологических процессов выполнения работ, связанных с конвертацией ТО и Р;

- разработка управляющих программ для автоматизированных систем/оборудования/станков и их наладка;

- разработка технологической части строительного проекта центра конвертации.

Кроме этого, необходимо учесть наличие летноиспытательной станции (центра) и таможенного пункта.

Полезным представляется рассмотреть опыт Российской Федерации в попытке создать в 20072011 гг. на ее территории центр конвертации, ТО и P в рамках реализации совместно с компанией Airbus программы конвертации пассажирских самолетов А320/A321 в грузовые [13-15]. Для достижения намеченных целей было создано (в 2007 г.) совместное предприятие, в котором 32\% акций получила EFW - дочерняя немецкая компания Airbus, по 25\% - российские корпорации «Иркут» и «Объединенная авиастроительная корпорация», 18\% - Airbus.

Запланированный срок реализации программы (операционная фаза) - 2013-2027 гг., общее количество конвертированных в этот период пассажирских самолетов А320/А321 - 210 единиц (14 самолетов в год).

Соответствующие работы планировалось выполнять: в Германии - на заводе EFW (г. Дрезден); в РФ - базе «Луховицкого авиационного завода им. П.А. Воронина» (филиал АО «РСК «МиГ», г. Луховицы, Московская обл.). В дальнейшем было принято решение о реализации указанной программы в Ульяновской области - в портовой особой экономической зоне «Ульяновск-Восточный» [15]. По оценкам европейских экспертов, всего на подготовку производственной площадки в РФ необходимо было потратить около 25-30 млн. дол. США (в ценах 2008 г.). В пользу принятия решения по созданию центра конвертации в Луховицах стало наличие:

- свободного корпуса, ранее предназначавшегося для производства региональных самолетов Ту-334 (перенесено на Казанский авиационный завод им. С.П. Горбунова);

- взлетно-посадочной полосы, соответствующей ТТХ самолетов А320/А321;

- квалифицированного инженерно-технического персонала (готовил «Луховицкий авиационный техникум»);

- летно-испытательного центра (им. А.В. Федотова) и таможенного пункта.

Несмотря на оптимистические прогнозы российских экспертов, производственный процесс так и не начался, и в 2011 году программа была остановлена. Основными причинами стали: 
- затягивание российской стороной сроков создания центра конвертации, ТО и $\mathrm{P}$ в результате отсутствия опыта и финансовых проблем, вызванных мировым финансово-экономическим кризисом (2008-2013 гг.);

- снижение спроса на конвертированные грузовые самолеты, обусловленное падением в этот период (более чем на 10\%) уровня мировой торговли. По имеющейся информации, только один заказ на конвертацию 30 самолетов А320/А321 удалось получить от лизинговой компании AerCap (г. Амстердам, Нидерланды).

3.2. Типовой перечень работ, выполняемых в процессе конвертации пассажирских самолетов в грузоbole

В типовой перечень работ входят [16]:

- демонтаж систем пассажирского салона;

- вырез проема грузового люка;

- установка двери грузового люка;

- доработка пассажирской двери;

- доработка пассажирских окон (бланкирование);

- установка барьерной стенки безопасности $9 \mathrm{~g}^{1}$;

- доработка пола грузовой кабины самолета (опускают ниже, чем на пассажирских версиях, оборудуют механизацией автоматической загрузки контейнеров);

- доработка кабины экипажа и авиационного оборудования;

- снятие и восстановление лакокрасочного покрытия (ЛКП);

- техническое обслуживание и ремонт.

Кроме этого, при пересчете на прочность конструкции самолета, возникает необходимость добавления в нее усиливающих элементов.

По имеющимся данным, трудоемкость конвертации пассажирского самолета Boeing 737-700 в грузо- вой составляет 35 тыс. чел.-час. Принимая за программу конвертации один самолет в месяц, эффективный месячный фонд времени - 176 часов (количество рабочих смен в месяце - 22, продолжительность рабочей смены -8 часов), численность основного производственного персонала (ОПП) - 200 человек. В свою очередь трудоемкость работ по конвертации для самолетов Airbus A320/A321 53 тыс. чел.-час, численность ОПП (при тех же условиях) составляет 300 человек.

С целью оптимизации процесса конвертации самолета производится поэтапное выполнение соответствующих работ, которое включает подготовительный, четыре основных и заключительный этапы [15]:

подготовительный этап включает подготовку:

- документации;

- персонала;

- материалов, инструментов;

- комплектующих блоков и агрегатов;

I этап включает:

- входной контроль самолета, оценка поточного технического состояния;

- взвешивание;

- снятие ЛКП, разборка и очистка;

- демонтаж пассажирского салона;

II этап включает:

- доработку пола в салоне (рис. 10);

- вырез проема под грузовой люк (рис. 11);

- доработку авиационного оборудования;

- монтаж погрузочной системы;

- доработку (бланкирование) пассажирских окон; III этап включает:

- монтаж барьерной стенки безопасности $9 \mathrm{~g}$ (рис. 12);

- установку грузового люка и двери (рис. 13);

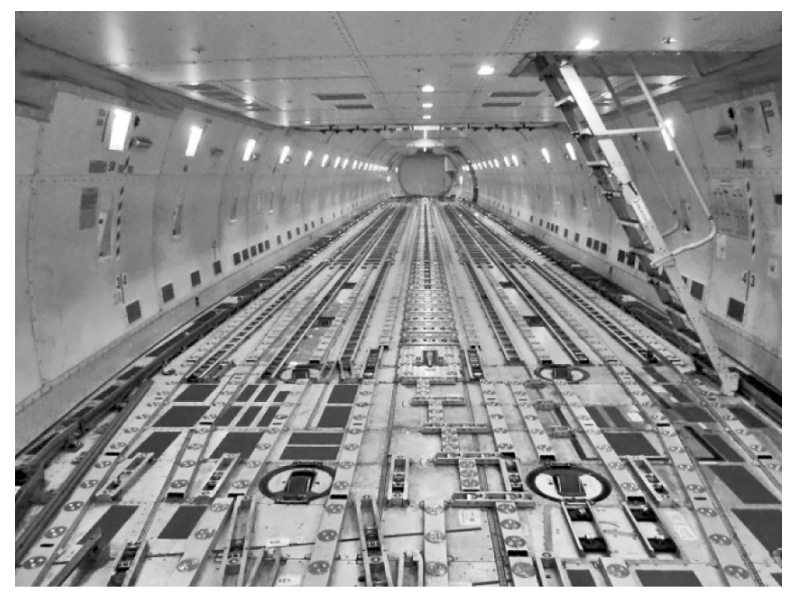

Рис. 10. Доработка пола в салоне самолета [18]

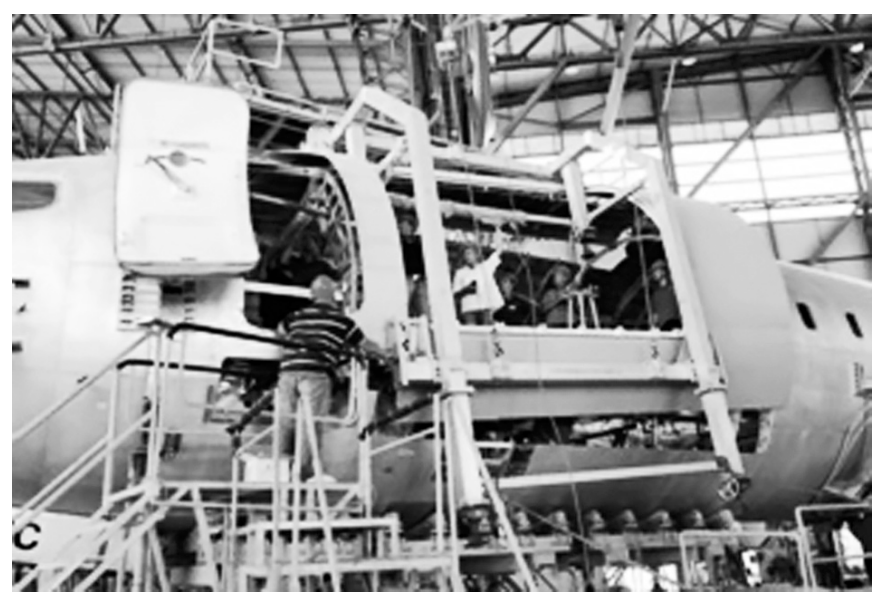

Рис. 11. Вырез проема под грузовой люк [19]

${ }^{1}$ Барьерная стенка безопасности 9g предназначена для: удержания веса груза с девятикратной перегрузкой с целью защиты экипажа; обеспечение герметичности кабины пилотов в случае разгерметизации фюзеляжа, а также обеспечения входа-выхода в транспортную кабину. 


\section{технологическив TC 1/2019}

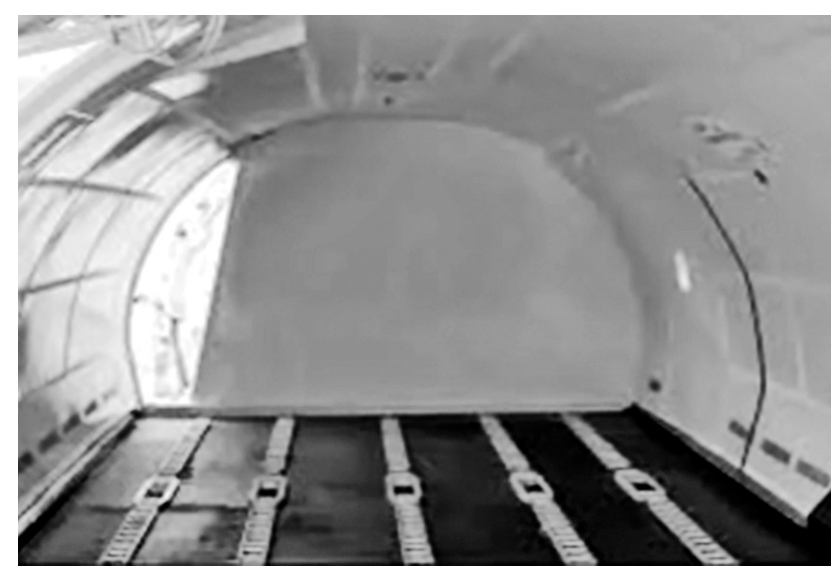

Рис. 12. Монтаж барьерной стенки безопасности 9g [20]

- сборку систем и оборудования, их регулировку;

- проверку герметичности;

- проверку под током всех систем самолета;

IV этап включает:

- завершение монтажных работ на самолете;

- проверку работоспособности систем;

- проверку герметичности систем;

- нанесение ЛКП;

- наземное опробование силовой установки;

- летные испытания после выполнения работ по конвертации, ТО и $\mathrm{P}$;

- заключительный этап включает (рис. 14):

- оформление технической документации;

- сертификацию самолета и передачу его заказчику.

\section{Заключение}

Результаты аналитического обзора позволяют констатировать следующее:

1. В период 2001-2018 гг. структура мирового парка и количество эксплуатируемых грузовых

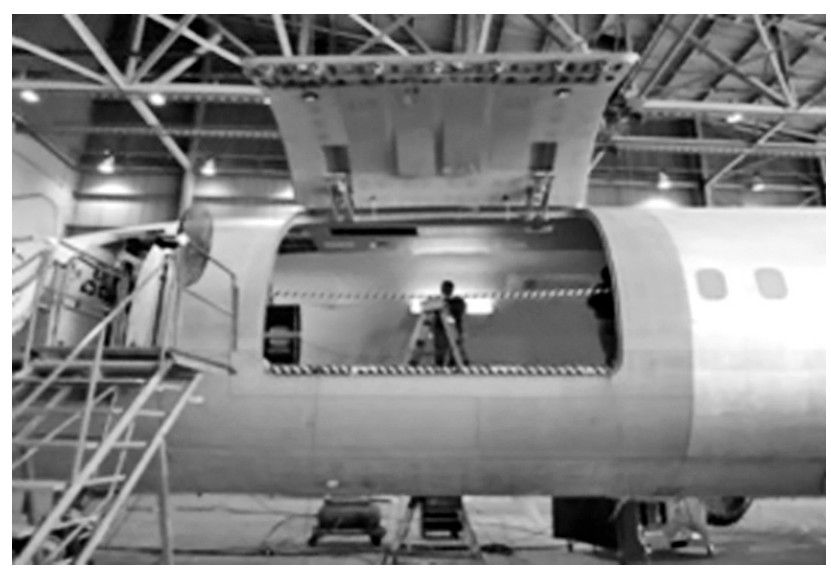

Рис. 13. Установка грузового люка и двери [21]

самолетов не претерпевали существенных изменений. В структуре парка преобладали конвертированные грузовые самолеты. Они составляли 65$75 \%$ общего количества грузовых самолетов.

Наиболее востребованными на рынке в этот период были конвертированные узкофюзеляжные пассажирские самолеты.

2. В анализируемом периоде стоимость комплекса работ, связанных с конвертацией пассажирских самолетов в грузовые составляла: от $\approx 2,5$ млн. дол. США для самолетов класса MD-80, Boeing B737-300 до $\approx 23$ млн. дол. США для самолета Boeing 747-400. Удельная стоимость составляла 65-77 дол. США/кг массы пустого самолета и 150-160 дол. США/кг массы пустого самолета соответственно.

3. Укрупненная структура стоимости конвертированного грузового самолета характеризуется основными составляющими:

- остаточная рыночная стоимость пассажирского самолета по достижении им 20-летнего срока

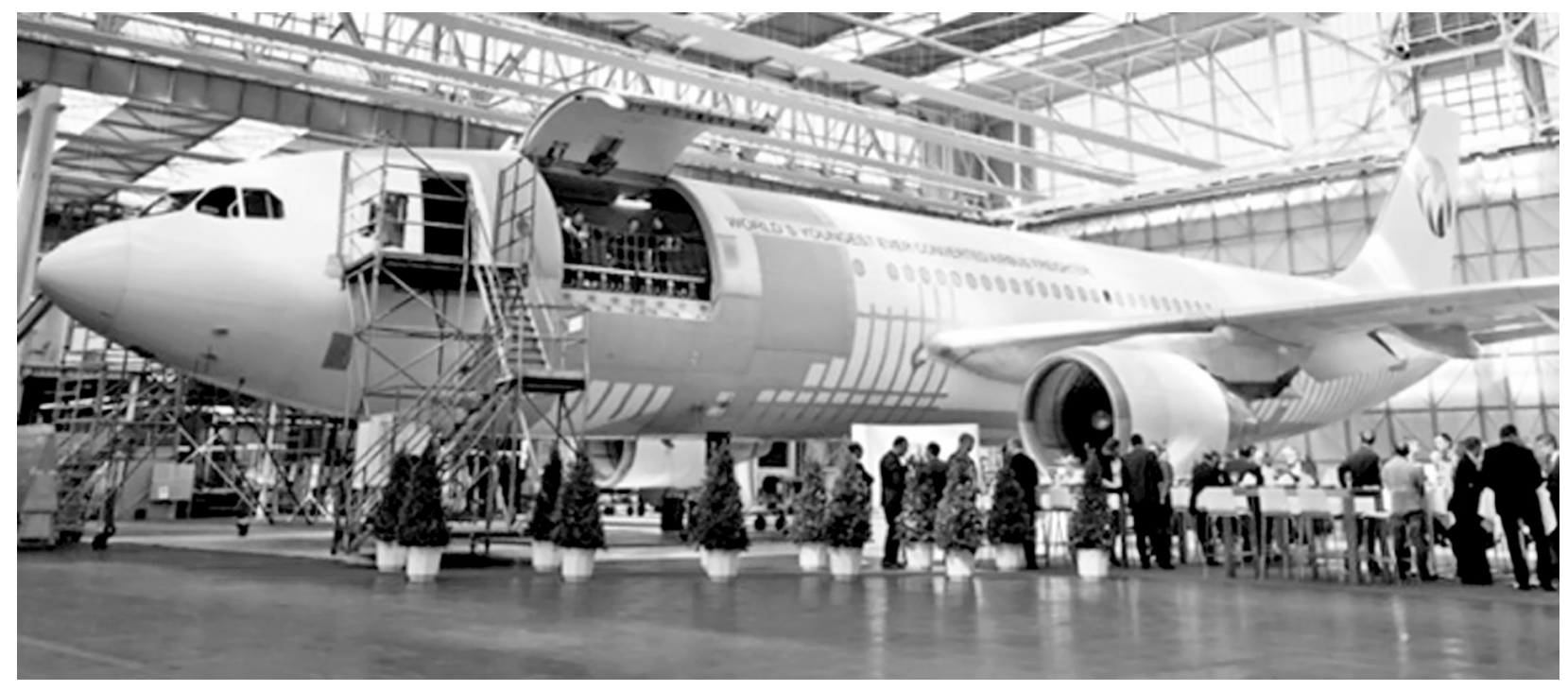

Рис. 14. Конвертированный грузовой самолета [22] 
эксплуатации (составляет 45\% стоимости конвертированного самолета);

- стоимость работ по конвертации (30\%);

- дополнительные расходы (25\%);

4. Разработанные компаниями Boeing и Airbus прогнозы, касающиеся перспектив развития мирового и региональных рынков конвертированных самолетов, охватывают период 2018-2037 гг. и свидетельствуют о следующем:

- общее количество мирового парка грузовых самолетов составит к концу прогнозируемого периода 2,7-3,2 тыс. единиц;

- в структуре мирового парка грузовых самолетов по-прежнему будут преобладать конвертированные самолеты - порядка 70\% общего количества самолетов транспортной категории;

- в структуре мирового парка конвертированных самолетов будут преобладать самолеты легкой и средней категорий;

- мировой парк конвертированных самолетов будет пополняться, в основном, за счет семейств самолетов В737 и А320/A321;

- в прогнозируемый период спрос на конвертированные самолеты семейств В737 составит $\approx 1000$ ед., А320/A321 - $\approx 600$ ед. Прогнозируется, что более $50 \%$ этих самолетов будет востребовано в Азиатско-Тихоокеанском регионе;

- стоимость одного конвертированного самолета, в зависимости от модели, будет находиться в пределах 7,3-20,5 млн. дол. США;

- емкость мирового рынка услуг по конвертации пассажирских самолетов в грузовые прогнозируется на уровне 10-12 млрд. дол. США. Это подтверждает мнение многочисленных экспертов, считающих, что услуги по конвертации в период до 2037 года будут востребованы на мировом и региональных рынках;

5. Учитывая вышеизложенное, а также имеющийся инфраструктурный и кадровый потенциал авиационной промышленности Украины, представляется целесообразным создание отечественных проектно-производственных структур, специализирующихся на предоставлении услуг по конвертации украинских и зарубежных пассажирских самолетов в грузовые.

\section{Литература}

[1] Кривов Г. А., Матвиенко В. А., Афанасьева Л. Ф. Мировая авиация на рубеже XX - XI столетий. Промышленность, рынки. К., 2003. 296 с.

[2] Current Market Outlook 2000 = Текущий обзор рынка 2000. Компания Boeing, 2000. URL :

http://www.as777.com/data/manufacturer/forecast/boeing_2000.pdf

[3] Current Market Outlook 2002 = Текущий обзор рынка 2002. Компания Boeing, 2002. URL: http://www.as777.com/data/manufacturer/forecast/boeing_2002.pdf

[4] Air Cargo Management Group. URL : http://aircargoworld.com.

[5] Кривов Г. А., Матвиенко В. А., Щербак А. А., Щередина Т. Н. Гражданское самолетостроение в начале XXI столетия. Деятельность ведущих мировых производителей. К., 2008. 167 с.

[6] Commercial market outlook 2018-2037 = Текущий обзор рынка 2018 - 2037. Компания Boeing, 2018. URL: https://www.boeing.com/resources/boeingdotcom/commercial/market/commercial-market-outlook/assets/downloads/2018-cmo-09-11.pdf

[7] Airbus forecasts freighter fleet growth of $65 \%$ through 2037. URL : https://cargofacts.com.

[8] Airbus expects freighter fleet to increase by $65 \%$ over the next 20 years. URL : https://www.aircargonews.net.

[9] Global Market Forecast 2018-2037 = Глобальный прогноз рынка 2018-2037. Компания Airbus, 2018. URL : https://www.airbus.com/aircraft/market/global-market-forecast.html

[10] Freighter Conversions. Capitalising on the resurgence in demand = Конвертация самолетов в грузовые. Воспользовавшись увеличением спроса. URL : https://www.iba.aero/.

[11] Current Market Outlook 2011-2030 = Текущий обзор рынка 2011 - 2030. Компания Boeing, 2011. URL : https://aviatingasia.files.wordpress. com/2012/09/ boeing_current_market_outlook_2011_to_2030.pdf

[12] Passenger to freighter conversions = Конвертация пассажирского в грузовой. Компания American friendship world air cargo corporation. URL : http://www.aircargopedia.com.

[13] Лантратов К. Без права на пенсию // Коммерсантъ business guide. 2008. № 59.

[14] Лантратов. К. Конвертация - очень лакомый кусок // Коммерсантъ business guide. 2008. № 59.

[15] Airbus Freighter Conversion Конвертация пассажирских самолетов Airbus A320/321 в грузовой вариант Корпорация «Иркут» - презентация, URL : http://www.myshared.ru/slide/59192/

[16] Boeing 767-323/ER (BDSF) - Untitled (Cargo Aircraft Management). URL : https://www.airliners.net/photo/ Untitled-Cargo-Aircraft-Management/ Boeing-767323-ER-BDSF/4859731

[17] Авиационное техобслуживание и ремонт: тренды и перспективы рынка. Центр транспортных стратегий, 28.02.2017. URL : ttps://cfts.org.ua/articles/

[18] 747-400 freighter interior, World Port. URL : https://www.flickr.com/ photos/wrightfamilyarchives/14650107580

[19] Do not wait for an MD-90 freighter. URL: https://www.aircargonews.net/ news/single-view/ news/do-not-wait-for-an-md-90-freighter.html

[20] AEI B737-200SF Freighter Conversion 8 Pallet Configuration Data Sheet. URL : http://www.aeronautical-engineers c o m / media/products 
/data_sheets/B737-200SF_8_Pallet_Spec_ Sheet.pdf

[21] AEI signs agreement for 30 B737-800SF conversions. May 18, 2016. URL : https://www.aircargoweek.com/ aei-signs-agreement-30-b737-800sf-conversions/
[22] Youngest-ever Airbus freighter conversion, Cargo Facts. August 12, 2011. URL : https://cargofacts.com/ youngest-ever-airbus-freighter-conversion/

Krivov G. A., Matvienko V. A., Rudko A. N., Baklan V. V.

Ukrainian Research Institute of Aviation Technology, JSC. Ukraine, Kyiv

\section{THE STATE AND PROSPECTS OF DEVELOPMENT OF THE WORLD MARKET OF SERVICES FOR THE CONVERSION OF PASSENGER AIRCRAFT INTO CARGO}

The article presents the results of an analytical review of the state and development prospects of the world, as well as regional markets of converted cargo aircraft. The main organizational and technical principles and operating experience of individual production structures of this sector of civil transport aviation were reviewed.

In a next step, it was analyzed necessary precondition for the establishment and successful activity in the market of new design and production structures specializing in the conversion of passenger aircraft into cargo. [dx.doi.org/10.29010/086.1]

Keywords: cargo airplane; converted cargo aircraft; world fleet of cargo aircraft; the structure of the world cargo fleet; the state of the world fleet of cargo aircraft; prospects for the development of a global fleet of converted cargo aircraft; center for conversion, maintenance and repair; the cost of converting passenger aircraft into cargo.

\section{References}

[1] Krivov G.A., Matvienko V.A., Afanasyeva L.F. World aviation at the turn of the XX-XI centuries. Industrial, markets. K., 2003. 296 p.

[2] Current Market Outlook 2000. Boeing. URL : http://www.as777.com/data/manufacturer/forecast/boeing_2000.pdf

[3] Current Market Outlook 2002. Boeing. URL : http://www.as777.com/data/manufacturer/forecast/boeing_2002.pdf

[4] Air Cargo Management Group. URL : http://aircargoworld.com.

[5] Krivov G.A., Matvienko V.A., Scherbak A.A., Scheredina T.N. Civil aircraft in the early twenty-first century. Activities of leading global manufacturers. K., 2008. 167 p.

[6] Commercial market outlook 2018-2037. Boeing, 2018. URL : https://www.boeing.com/resources/boeingdotcom/commercial/market/commercial-market-outlook/assets/downloads/2018-cmo-09-11.pdf

[7] Airbus forecasts freighter fleet growth of 65\% through 2037. URL : https://cargofacts.com.

[8] Airbus expects freighter fleet to increase by $65 \%$ over the next 20 years. URL : https://www.aircargonews.net.

[9] Global Market Forecast 2018-2037. Airbus, 2018. URL : https://www.airbus.com/aircraft/market/global-market-forecast.html

[10] Freighter Conversions. Capitalising on the resurgence in demand. URL : https://www.iba.aero/

[11] Current Market Outlook 2011-2030. Boeing, 2011. URL : https://aviatingasia.files.wordpress. com/2012/09/boeing_ current_market_outlook_2011_to_2030.pdf

[12] Passenger to freighter conversions. American friendship world air cargo corporation. URL : http://wwwaircargopedia.com.

[13] Lantratov K. Without the right to retire // Kommersant business guide. 2008. № 59 .

[14] Lantratov K. Conversion - a very tasty piece // Kommersant business guide. 2008. № 59.

[15] Airbus Freighter Conversion. Conversion of passenger aircraft Airbus A320/321 in the cargo version. Corporation «Irkut» - presentation, URL : http://www.myshared.ru/slide/59192/

[16] Boeing 767-323/ER (BDSF) - Untitled (Cargo Aircraft Management). URL : https://www.airliners.net/photo/ Untitled-Cargo-Aircraft-Management/ Boeing-767-323-ER-BDSF/4859731

[17] Aviation maintenance and repair: trends and market prospects. Center for Transport Strategies, 28.02.2017. URL : ttps://cfts.org.ua/articles/ 
[18] 747-400 freighter interior, World Port. URL : https://www.flickr.com/ photos/wrightfamilyarchives/14650107580

[19] Do not wait for an MD-90 freighter. URL : https://www.aircargonews.net/ news/single-view/news/do-not-wait-foran-md-90-freighter.html

[20] AEI B737-200SF Freighter Conversion 8 Pallet Configuration Data Sheet. URL : http://www.aeronauticalengineers.com/media/products/data_sheets/B737-200SF_8_Pallet_Spec_Sheet.pdf

[21] AEI signs agreement for 30 B737-800SF conversions. May 18, 2016. URL : https://www.aircargoweek.com/aei-signsagreement-30-b737-800sf-conversions/

[22] Youngest-ever Airbus freighter conversion, Cargo Facts. August 12, 2011. URL: https://cargofacts.com/youngest-everairbus-freighter-conversion/ 